\title{
The dynamics of IWRM policies in a water scarce catchment in Kenya, application of WEAP21 model
}

\author{
E. M. Akivaga ${ }^{1}$, F. A. O. Otieno ${ }^{2}$, E. C. Kipkorir ${ }^{3}$, \\ J. Kibiiy ${ }^{1} \&$ V. O. Okumu ${ }^{1}$ \\ ${ }^{I}$ Department of Civil and Structural Engineering, Moi University, Kenya \\ ${ }^{2}$ Technology, Innovations and Partnerships, \\ Durban University of Technology, South Africa \\ ${ }^{3}$ School of Environmental Studies, Moi University, Kenya
}

\begin{abstract}
Integrated water resources management (IWRM) is being embraced by many countries. Kenya is implementing a new water policy formulated along IWRM principles. The newly formed river basin organisations grapple with issues of sustainability, water allocation, resource quality objectives, equity, environmental flows among others. Kenya experiences water scarcity and stress. This research applied the Water Evaluation and Planning System (WEAP21) model to test a systems approach in evaluating the impact of changes in water policy and water development in Perkerra catchment in Kenya. The upper catchment has humid to semi-humid climatic conditions while the lower catchment experiences semi-arid to arid climatic conditions. Biophysical and human interventions were modelled in WEAP21. The scenarios analysed the impact of the new water policy of equitable water allocation, maintaining the reserve and ecological flows. The impact of increasing water storage and irrigation efficiency was evaluated. The reference scenario was validated using flows at the catchment observation station 2EE7B. The Tennant method was used to determine minimum environmental flows. From the analyses, one dam project will reduce water deficit by $5 \%$. However, higher irrigation efficiency reduces the deficit by $15 \%$. The implementation of two dam projects improves
\end{abstract}


demand coverage by $20 \%$, including environmental flows. The findings indicate that more efforts should be directed towards improving irrigation efficiency.

Keywords: Perkerra, integrated water resources management, demand, water allocation, environmental flows, WEAP21, water scarcity.

\section{Introduction}

Integrated water resources management (IWRM) is defined as a process which promotes the coordinated development and management of water, land and related resources in order to maximize resultant economic and social welfare in an equitable manner without compromising the sustainability of vital ecosystems [1]. The last two decades has seen a call for integration in water management. Various international and national agencies have taken up a role in assisting countries develop a water policy based on IWRM principles (GWP, UN, DFID, SEI, BGR). The status report to the UN by Young et al. [2] traces progress of IWRM implementation and highlights various issues. Developed countries seem to have advanced on major issues of IWRM, but developing countries have shown some improvement at the national level in policy formulation. However, more needs to be done to implement the various policies and plans, the report points out. It is generally agreed that lack of coordinated policy implementation between government departments and practices of different water sector use that impact on water are major impediments to the success of IWRM implementation [3, 4].

Dzwairo et al. [4] points out that the process of integrating the management of natural resources and human activities can yield definite gains to the environment. The challenge is the task of operationalizing and implementing such a process. Water problems of the world are neither homogenous, nor constant or consistent over time. They often vary very significantly spatially and between seasons even in the same country. Biswas [5] points out that solutions to water problems depend not only on water availability, but also on many other factors, among which are the processes through which water is managed, competence and capacities of the institutions that manage them, prevailing sociopolitical conditions that dictate water planning, development and management processes and practices, appropriateness and implementation statuses of the existing legal frameworks, availability of investment funds, social and environmental conditions of the countries concerned, levels of available and usable technology, national, regional and international perceptions, modes of governance. It is argued that the definition thus presented by GWP has 'lofty phrases' that have little practical importance [4, 5].

Some studies indicate that IWRM has a direct bearing in improving livelihoods [6]. For economic exchange to become beneficial, two conditions must be met. First, the sustainability of the ecosystem must be guaranteed. Secondly, the partners to the economic exchange must be satisfied that the basis of the exchange is equitable [4]. Dzwairo et al. [4] notes that for the water economy, neither condition is met, hence the unsustainable situation that many developing countries find themselves in, where fresh water resources are 
deteriorating. Dzwairo et al. [4] rather proposes a Systems Thinking Approach (STA) to IWRM as opposed to the 'lofty' definition of IWRM.

\subsection{IWRM in Kenya}

Kenya is no exception to the challenges of implementing IWRM. The Water Act 2002 [7] became operational in 2005. This introduced a radical change in policy framework and institutional organisation [8]. The catchment became the delineated zone for water resources management as shown in Figure 1(a), (b).

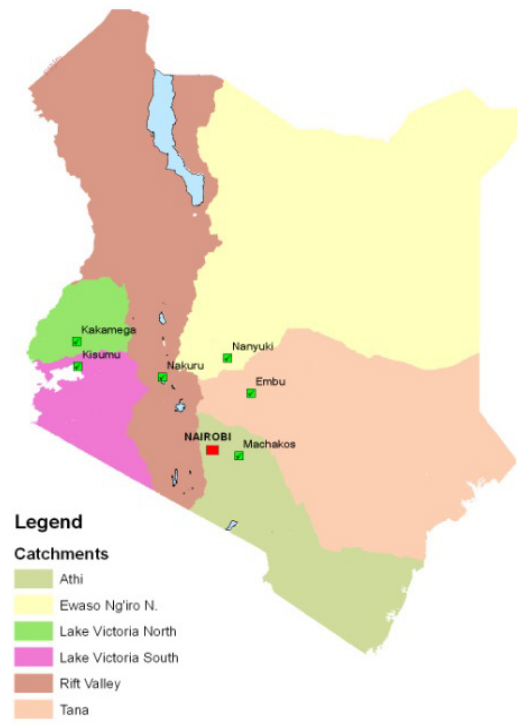

(a)

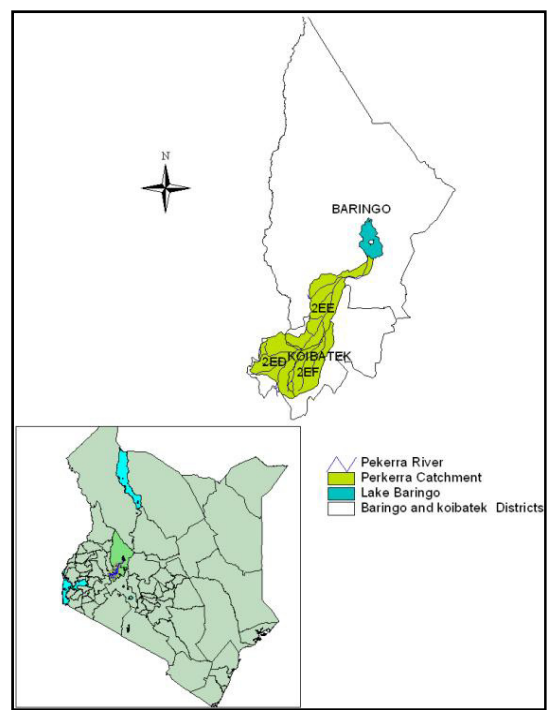

(b)

Figure 1: (a) The six major water catchment areas in Kenya, (b) the Perkerra catchment.

Water resources management is conducted in an inclusive approach through the Catchment Area Advisory Committees (CAAC). The up-down and down up system of management and decision making was envisaged. This led to the formation of Water Users Associations (WRUA) at the lowest institutional level. The fundamental objective outlined in the National Water Resources Management Strategy (NWRMS) [8], is managing Kenya's water resources to achieve equitable access to water resources and their sustainable and efficient use. The NWRMS was formed under a backdrop of various challenges: Kenya is a water scarce-country with renewable fresh water of $647 \mathrm{~m}^{3}$ per capita per annum. This figure is projected to reduce to $235 \mathrm{~m}^{3}$ per capita per annum by 2025. The safe yield of the renewable fresh water is about $40 \%$ with $60 \%$ required for the reserve and sustenance of ecological biodiversity. About $4.3 \mathrm{~m}^{3}$ per capita per year is available storage, representing about $15 \%$ development of the renewable fresh water [8]. 
The annual safe yield is faced by extremely variable rainfall patterns not only spatially and temporal, but also in rainfall intensities. This, coupled with high rates of catchment degradation due to poor land management practices and hydrometric network, has led to over abstraction of surface water in some parts of the country.

Water managers of the various catchments together with stakeholders have formulated Catchment Management Strategies (CMS). The CAAC has to grapple now with various challenges; among them is equitable allocation, resource quality benchmarks, the reserve and environmental flows. Several studies indicate that systems oriented models could facilitate stakeholder participation and increase focus on the whole picture [4, 9-11]. In such models, hydrological data, water development projects, policy and other metaphysical aspects of catchment hydrology and socio-economic factors are analysed in an interactive computer based system. Modelling various scenarios gives the stakeholders an opportunity to test and the impacts of catchment management proposals. This study used the systems approach to model various scenarios in Perkerra sub-catchment in the Rift Valley catchment area in Kenya Figure 1b. The catchment is highly water-scarce, with the upper catchment being semihumid and the mid and lower catchment having semi-arid to arid climatic conditions. Upstream and downstream problems are common especially with the formation of the WRUA. The WRUAs are mostly composed of community representatives from the villages and towns who may not have knowledge in IWRM.

The Perkerra River is the only remaining perennial river that flows to Lake Baringo. The river is the lifeline of Perkerra irrigation scheme downstream in the arid plains. It is also the only source of fresh water available to downstream users, mostly pastoralist communities. The upper catchment is densely populated. Degradation of the catchment's water tower [2] and other factors have led to reduction of stream flows over the last two decades.

\section{Methodology}

The Water Evaluation and Planning system (WEAP21) was used to model the catchment. WEAP21 was developed by the Stockholm Environmental Institute, USA. WEAP21 is a surface and ground water tool based on water balance accounting principles, which can test alternative sets of supply and demand conditions [13]. It integrates a range of physical hydrologic processes with the management of demands and installed infrastructure in a seamless and coherent manner [14]. Both the engineered and biophysical components of a water system are represented to facilitate multi-stakeholder water management dialogue on a broad range of topics, including sectoral demand analysis, water conservation, water rights and allocation priorities, reservoir operations, hydropower generation, pollution tracking, ecosystem requirements, and project cost-benefit analysis. It is designed for comparative analysis where a base case (scenario) is developed and then alternative scenarios are created and compared to the base scenario. It is useful for what-if analysis of various policy scenarios and long 
range planning studies [13]. It provides a platform for detailed modelling of water demand management strategies of the various water sectors (e.g. municipal, agriculture). WEAP21 has been adapted to many catchments [11, 15-18]. The model was applied to Perkerra catchment to simulate IWRM because it addresses the gap between water management and catchment hydrology following a systems approach. Rainfall runoff is simulated using either the Food and Agriculture Organization (FAO rainfall-runoff) or the soil moisture sub-routines in WEAP21. The model simulation is structured as a set of scenarios with monthly time steps. WEAP solves the water allocation problem by a linear programme with the objective of maximizing demand node satisfaction constrained by water availability, demand priority, supply priority and proximity to supply.

\subsection{Estimating the reserve}

There are many methodologies used to quantify environmental flows. The methods can be put into three broad categories as historic flow, hydraulic and habitat based methods [19-21]. The building block methodology refined in South Africa is the most comprehensive and has become the common approach used King et al. [22]. However, the Tennant method [24] is mostly used to estimate environmental flows when using discharge time series [19, 22, 23, 25]. The method uses a percentage of average annual flow (AAF) to determine fish habitat quality. In his study from 58 cross sections from 11 streams in Montana, Nebraska, and Wyoming, Tennant concluded that $10 \%$ of AAF is the minimum for short term fish survival, $30 \%$ of AAF is considered to be able to sustain fair survival conditions, and $60 \%$ of AAF is excellent to outstanding habitat [24]. These quantities are employed internationally, regardless of physical and hydrologic setting, due to the simplicity of using only the average annual hydrograph [20]. This method has the advantage of maintaining the hydraulic characteristics of a river in proportion to the river size. It tends to reflect the river under natural flow $[19,25]$. There is a close relationship between natural flow and existing ecology, thus this method is suitable for providing the desired level of ecological function of a river. Mann [20] recommends this method for instream flow protection scenarios. Studies by Jowett [19] indicate that this method assumes that lower than natural flows will harm a rivers ecosystem and thus the receiving waters ecology in the case of Lake Baringo. This is therefore a plausible technique for estimating environmental flows by use of historical flow measurements.

Rainfall, discharge, water use and soil data were obtained from Kenya Meteorological Department (KMD), Ministry of water, Water Resources Management Authority (WRMA) and International Livestock Research Institute (ILRI) respectively. The government of Kenya has proposed the development of several dams in the catchment. The two dams considered at Chemususu and Radat have reservoir capacities of 13million and 9 million cubic meters respectively. Thus, four scenarios were analysed: Impact of increasing storage in the catchment by one and two dams respectively and the impact of increased irrigation efficiency on the two scenarios. The reference scenario was validated 
using flows at the catchment observation station 2EE7B. The schematic presentation of the catchment is shown in Figure 2. The policy requirements were modelled in terms of allocation priority, instream flow requirements and demand management strategies. Ecological and the reserve flows were given highest priority in allocation.

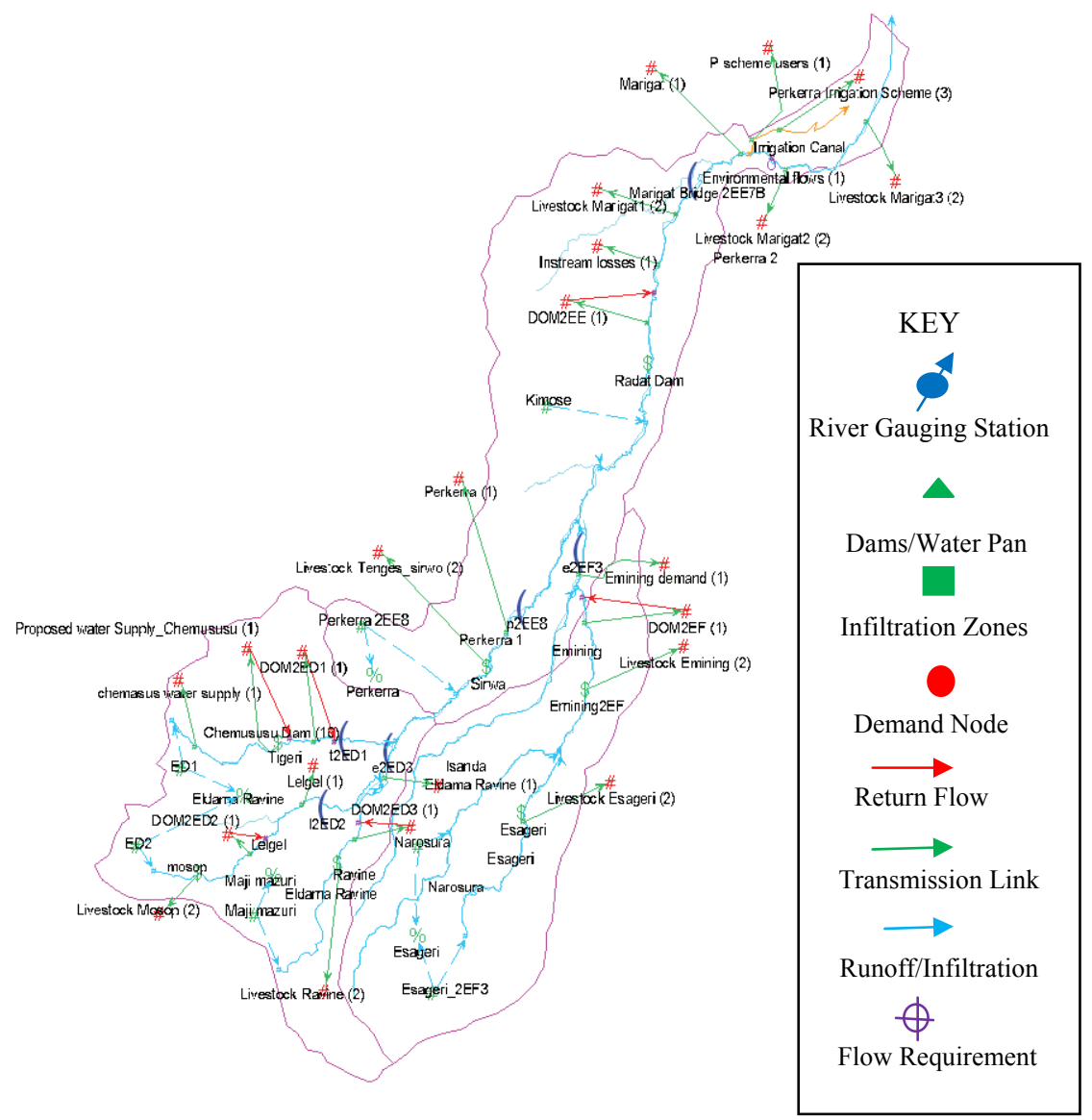

Figure 2: Schematic presentation of Perkerra catchment in WEAP21. (See online for colour version.)

The two dams Chemususu and Radat are located in the upper catchment and mid catchment respectively. Perkerra Irrigation Scheme is a gravity flow furrow irrigation system downstream with a potential of 2840ha. developed for furrow irrigation. The rural domestic uses and livestock consumptions were modelled as lumped consumptions at sub-catchment nodes. 


\section{Results and discussions}

The reference scenario is a representation of the system as it is. The year 2000 to 2009 was used to calibrate and validate the model. The results are shown in Figure 3, where Qo is the observed flow and Qm is the simulated flows at the catchment observation station 2EE7B. The model efficiency (EF) was 0.99 and r-squared was $89 \%$. The model was therefore used to perform scenario analysis of various management options. The flows depict very sharp peaks for such a catchment. Analysis of historical flow time series between 1962 and 2000 indicate that the hydrograph peaks have been getting steeper with time. This is an indication of low infiltration rates leading to quick flows.

The summary of scenarios created is shown in table 1 .

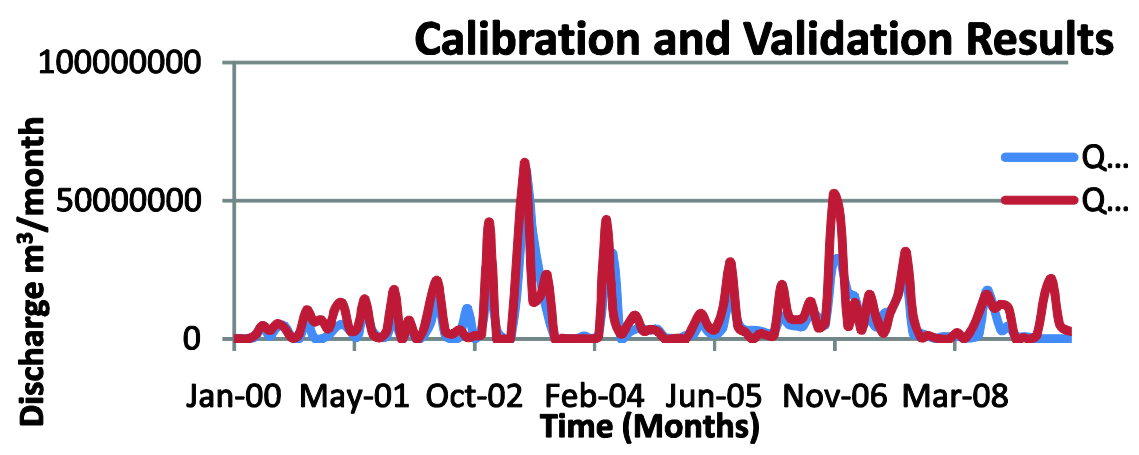

Figure 3: Calibration and validation results.

Table 1: $\quad$ Summary of scenarios created for analysis.

\begin{tabular}{|c|c|c|c|c|}
\hline $\begin{array}{c}\text { Level of } \\
\text { scenario } \\
\text { analysis }\end{array}$ & Scenario & Remarks & Scenario & Remarks \\
\hline $\mathbf{0}$ & Reference & $\begin{array}{c}\text { Simulations of } \\
\text { catchment with no } \\
\text { changes to system }\end{array}$ & Reference & $\begin{array}{c}\text { Simulations of } \\
\text { catchment with no } \\
\text { changes to system }\end{array}$ \\
\hline $\mathbf{1}$ & $\begin{array}{c}\text { One Dam } \\
\text { (Chemususu) }\end{array}$ & $\begin{array}{c}\text { One reservoir in } \\
\text { catchment for storage } \\
\text { and flow regulation } \\
\text { only }\end{array}$ & $\begin{array}{c}\text { Water } \\
\text { resources } \\
\text { development }\end{array}$ & $\begin{array}{c}\text { Two reservoirs in } \\
\text { catchment for flow } \\
\text { storage and flow } \\
\text { regulation only. }\end{array}$ \\
\hline $\mathbf{2}$ & $\begin{array}{c}\text { Chemususu } \\
\text { dam project. }\end{array}$ & $\begin{array}{c}\text { Water supply project } \\
\text { to Nakuru and other } \\
\text { towns and } \\
\text { implementation of } \\
\text { reserve flows to Lake } \\
\text { Baringo }\end{array}$ & $\begin{array}{c}\text { Increased } \\
\text { water demand }\end{array}$ & $\begin{array}{c}\text { Water supply project } \\
\text { to Nakuru and other } \\
\text { towns and } \\
\text { implementation of } \\
\text { reserve flows to Lake } \\
\text { Baringo }\end{array}$ \\
\hline $\mathbf{3}$ & $\begin{array}{c}\text { Increased } \\
\text { irrigation } \\
\text { efficiency 1 }\end{array}$ & $\begin{array}{c}\text { Improved irrigation } \\
\text { efficiency at Perkerra } \\
\text { irrigation scheme. }\end{array}$ & $\begin{array}{c}\text { Increased } \\
\text { irrigation } \\
\text { efficiency 2 }\end{array}$ & $\begin{array}{c}\text { Improved irrigation } \\
\text { efficiency at Perkerra } \\
\text { irrigation scheme. }\end{array}$ \\
\hline
\end{tabular}


Level 0 is the reference scenario from which other scenarios are developed. The data available in a lower level scenario is "inherited" by the subsequent scenario.

The impact of the various scenarios in management strategies is evaluated by analysing its impact on meeting the demand and availing water for the instream flow requirements and ecological flows downstream to Lake Baringo. The impact of the various management scenarios on demand is shown in Figure 4 and 5 . The results indicate that average unmet demands for the simulated period varied depending on the management and development level. The average unmet demand for the simulated period shows that there is marginal improvement when Chemususu dam project is implemented. Improved irrigation efficiency from the current $23 \%$ to $45 \%$ shows reduction in overall unmet demand by between $8 \%$ and $25 \%$.

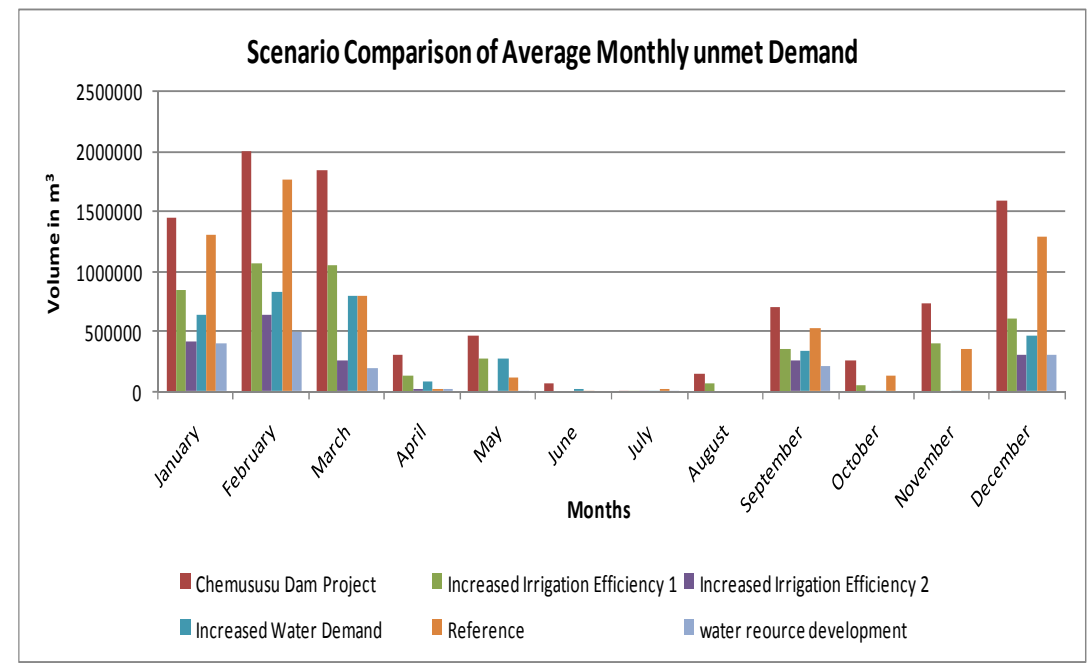

Figure 4: Average monthly unmet demand between 2000 to 2010 for the simulated scenarios.

A second dam project "Water resources development", dedicated for flow regulation purposes seems to be a good solution. However the economic justification of such a project in developing countries may be an uphill task.

Increased water demand is brought about by the demands placed on the catchment by the construction of the second dam project. This scenario is much better than the other realistic scenarios with demand coverage more than $80 \%$ in any month, figure 4 . This scenario avails the highest amount of ecological flow at above $90 \%$ supply as shown in figure 6. Improved irrigation efficiency on this scenario shows tremendous improvement of demand coverage and ecological flows.

The introduction of the reserve and ecological flows downstream on the reference scenario increases the unmet demand by more than $50 \%$. 


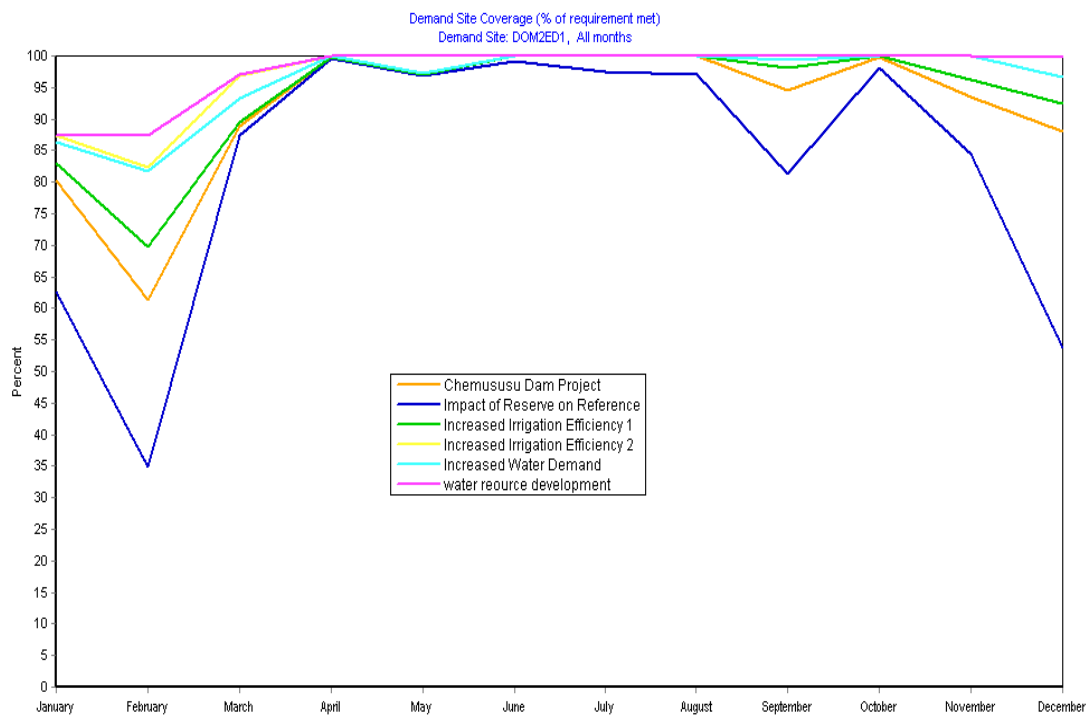

Figure 5: $\quad$ Average monthly demand coverage as percentage.

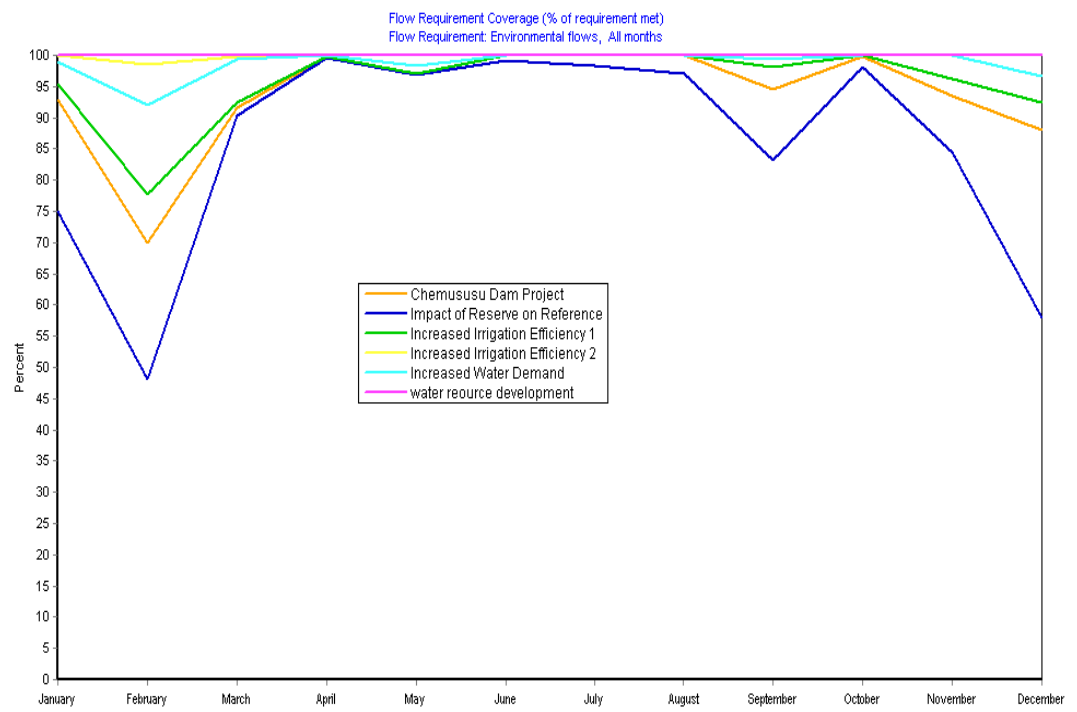

Figure 6: Ecological flow demand coverage.

Implementing reserve flows cannot be attained because there are no systems currently to regulate the flow in the river. On the other hand, water use conflicts will increase. Meanwhile the environment suffers. This indicates it may not be possible to achieve sustainable flow regulation without control systems in place, formation of WRUA's alone will not suffice. 
The simulated scenarios assumed that systems for demand side management and supply side management are in place. However, there are virtually no abstraction control structures. Water rights cannot be assured to the users, especially downstream WRUAs. Accessibility to water is a challenge and most of the populations downstream walk long distances to fetch water for domestic and to water their animals at the river. Implementation of IWRM will require the farmers at Perkerra irrigation scheme to invest in methods that will increase irrigation efficiency.

The sharp peaks of flow hydrographs at the catchment observation station are an indication of catchment degradation and low natural storage capacity in the catchment. It is imperative that catchment restoration measures programmes should be initiated upstream.

\section{Conclusions}

The need for holistic approach in achieving sustainable water resources management cannot be overemphasised. However, the way of implementation should be more focused on systems approach where the focus is on bringing everyone on board. The above study and many other examples $[4,25,26]$ highlight the importance of a systems approach. This allows the tracing of impacts of changes in policy, pollution, demand and flow reducing activity in a stream or catchment.

The WEAP21 model can be used to perform a systems analysis of a water catchment. This could be used to evaluate impacts the of IWRM policies in a water scarce catchment.

The challenges of IWRM in water stressed catchment are mainly on the compromise users need to make on often basic uses that are guaranteed for sustenance of life.

\section{Acknowledgements}

The authors would like to acknowledge the financial support received from the MUK-VLIR-UOS programme in conducting the above research, and the Department of Civil and Structural Engineering, Moi University and the SubRegional WRMA Office Kabarnet for their contributions.

\section{References}

[1] Global Water Partnership (GWP). Integrated Water Resources Management, TAC Background papers, No. 4. SE-1052 5, Stockholm, Sweden, 2000.

[2] Young G, Shah B, Kimaite F. Status report on IWRM and water efficiency plans. Prepared for the 16th session of the Commission on Sustainable Development - May 2008. 
[3] Funke N, Oelofse SHH, Hattingh J, Ashton PJ, Turton AR. IWRM in developing countries: Lessons from the Mhlatuze Catchment in South Africa. Phys. Chem. Earth, Parts A/B/C. 32: 1237-1245, 2007.

[4] Dzwairo B, F. A. O. Otieno, G. M. Ochieng, Making a case for systems thinking approach to integrated water resources management (IWRM), International Journal of Water Resources and Environmental Engineering Vol.1 (5), pp. 107-113, 2010.

[5] Asit K. Biswas., Integrated Water Resources Management: A Reassessment A Water Forum Contribution, International Water Resources Association, Water International, Volume 29, 2, pp. 248-256, 2004

[6] Kumbulani Murenga, The Impact of Integrated Water Resources Management (IWRM) on Poverty Alleviation, 4th WaterNet/Warfsa Symposium: Water, Science, Technology \& Policy Convergence and Action by All, 15-17, October 2003.

[7] Government of Kenya (GOK). The Water Act (2002). Government Printer, Nairobi, Kenya, 2002.

[8] Government of Kenya (GoK) WRMA, The National Water Resources Management Strategy (NWRMS), Nairobi, Kenya, 2007.

[9] King JM, Tharne RE, DeVilliers MS (Eds)., Environmental Flow Assessments for Rivers: Manual for the Building Block Methodology. Pretoria, South Africa, p. 339, 2000.

[10] Tippett J., The value of combining a systems view of sustainability with a participatory protocol for ecologically informed design in river basins. Environ. Modell. Softw. 20: 119-139, 2005.

[11] Levite H, Sally H, Cour J., Testing water demand management scenarios in a water-stressed basin in South Africa: application of the WEAP model, Science Direct Journals, Phys. Chem. Earth., 28: 779-786, 2003.

[12] Kipkorir E.C., Raes D., and Labadie J., Seasonal Water Production Functions and Yield Response Factors for Maize and Onion in Perkerra, Kenya, Agricultural Water Management 56 , 229-240, 2002.

[13] Assata HE, van Beek BC, Borden CP, Gijsbers DA, Jolma ES, Kaden FM, Kaltofen FJW, Labadie GDP, Loucks HNWT, Quinn IJ, Sieber IA, Sulis KWJ, Werick I, Wood DMM., Generic Simulation Models for Facilitating Stakeholder Involvement in Water Resources Planning and Management: a Comparison, Evaluation, and Identification of Future Needs, Environmental Modelling, Software and Decision Support, Elsevier 2008, (1574-101X), pp. 230-243, 2008.

[14] Yates D, Sieber J, Purkey DN, Huber-Lee A., WEAP21; A Demand, Priority, and Preference-Driven Water Planning Model Part1: Model Characteristics, Water Int., 30(4): 487-500. 2005.

[15] Alfara A., Modelling Water Resource Management in Lake Naivasha. Msc. Thesis. International Institute for Geo-information Science and Earth Observation, the Netherlands, 2004.

[16] E. M. Akivaga, F. A. O. Otieno, E. C. Kipkorir, J. Kibiiy and S.M. Shitote., Impact of introducing reserve flows on abstractive uses in water stressed 
Catchment in Kenya: Application of WEAP21 model, International Journal of the Physical Sciences Vol. 5(16), pp. 2441-2449, 2010.

[17] Hagan I., Modelling the Impact of Small Reservoirs in the Upper East Region of Ghana. MSc. Thesis, Lund University, Sweden, 2007.

[18] Vogel RM, Sieber J, Archfield SA, Smith MP, Apse CD, Huber-Lee A., Relations among storage, yield, and instream flow, Water Resour. Res., 43: W05403, doi: 10.1029/2006WR005226, 2007.

[19] Jowett IG., Instream Flow Methods: A Comparison of Approaches Regulated Rivers: Res. Manage., 13: 115-127, 1997.

[20] Mann JL., Instream Flow Methodologies: An Evaluation Of The Tennant Method For Higher Gradient Streams In The National Forest System Lands In The Western U.S. Master of Science Thesis, Colorado State University Fort Collins, Colorado, 2006.

[21] Sun T, Yang ZF., Calculating methods for ecological flows in estuary and its application in Haihe River basin, International Society for Environmental Information Sciences, Environmental Informatics Archives, 2: 464-470, 2004.

[22] King JM, Tharme RE, de Villiers MS (Eds), Environmental Flow Assessments for Rivers: Manual for the Building Block Methodology (Updated Edition). Water Research Commission Report No TT 354/08, Pretoria, South Africa, 2008.

[23] Acreman M, Dunbar MJ., Defining Environmental Flows Requirements: a review, Hydrol. Earth Syst. Sci., 8(5): 861-876, 2004.

[24] Tennant DL., Instream flow regimens for fish, wildlife, recreation and related environmental resources. Fisheries, 1(4): 6-10, 1976.

[25] Beecher HA., Standards for instream flows, Rivers, 1: 97-109, 1990.

[26] Chan SI. Huang SL., A systems approach for the development of a sustainable community - the application of the sensitivity model (SM). J. Environ. Manage., 72: 133-147, 2004. 